\title{
Üniversite Öğrencilerinde Öznel İyi Oluş: Yaşamda Anlam, İyimserlik ve Umudun Rolü*
}

\author{
Pınar DURSUN**
}

\section{Öz}

Pozitif psikoloji ekolü ile öznel iyi oluş, anlamlı yaşam, umut ve iyimserlik gibi kavramlar en fazla araștırılan konular haline gelmiștir. Nitekim, pek çok araștırma, yaşamında anlam olduğunu belirten, iyimser ve umutlu bireylerin, fiziksel ve psikolojik açıdan daha sağlıklı olduklarını ortaya koymuştur. Bu araștırmada, yaşamda anlam algısı, iyimserlik ve umut düzeylerinin öznel iyi oluş kavramıyla olan ilișkisi incelenmiștir. Üniversite öğrencilerinden oluşan örnekleme, 984 (582 kadın, 402 erkek; Ort $_{\text {yas }}=21.26$, $S S=1.69)$ Yaşamın Anlamı Anketi, Yaşam Yönelimi Testi, Umut Ölçeği, Olumlu-Olumsuz Duygu Ölçeği ve Yaşam Doyumu Ölçeği uygulanmıştır. Elde edilen veriler Yapısal Eşitlik Modeli (YEM) yoluyla incelenmiştir. Tüm değişkenlerin öznel iyi oluşu anlamlı olarak yordadığı görülmektedir, yani yaşamda anlama sahip olma, iyimserlik ve umut, öznel iyi oluş ile olumlu ve doğrudan ilișkidir ve diğer değişkenlere göre en güçlü yordayıcı iyimserliktir.

Anahtar Kelimeler: Öznel iyi oluş, Yaşamda anlam, İyimserlik, Umut, Üniversite öğrencileri, Türkiye

\section{Subjective Well-being in University Students: The Role of Meaning, Optimism and Hope in Life}

\begin{abstract}
With the school of positive psychology, concepts such as subjective well-being, hope, meaningful life and optimism have become the well-researched topics. Indeed, many studies have shown that optimistic and hopeful individuals who indicate meaning in their lives are physically and psychologically healthier. In this study, the relationship between sense of meaning in life, optimism and hope levels in relation to subjective wellbeing were examined. A total of 984 (582 female and 402 male) with the mean age of $21.26(S D=1.69)$ university students filled Positive-Negative Affect Schedule, Satisfaction with Life Scale, Meaning in Life Questionnaire, Life Orientation Test, The Hope Scale. The obtained data were analyzed by Structural Equation Modelling (SEM). All the variables
\end{abstract}

\section{Özgün Araştırma Makalesi (Original Research Article) \\ Geliş/Received: 21.03 .2020 \\ Kabul/Accepted: 10.08 .2020 \\ DOI: https://dx.doi.org/10.17336/igusbd.704651}

* Not: Bu çalışma yazarın doktora tezinden türetilmiştir. DURSUN, P. (2012). The role of meaning in life, optimism, hope, coping styles in subjective well being. [Yaşamın anlamı, iyimserlik, umut ve başa çıkma stillerinin öznel iyi oluş üzerindeki rolü], Orta Doğu Teknik Üniversitesi, Sosyal Bilimler Ensititüsü, Ankara. Tez danışmanı: Prof. Dr. Esin TEZER.

${ }^{* *}$ Dr. Öğr. Üyesi, Afyon Kocatepe Üniversitesi, Psikoloji Bölümü, Afyonkarahisar, Türkiye, E-posta: pdursun@aku.edu.tr ; dursun.pinar@gmail.com ORCID https://orcid.org/0000-0002$\underline{1451-0998}$ 
predicted subjective well-being significantly, that is to say, having a meaningful life, optimism and hope are in positive and direct relations with happiness and the most powerful predictive variable is optimism.

Keywords: Subjective well-being, Meaning in life, Optimism, Hope, University students, Turkey

\section{Giriş}

Pozitif psikoloji kapsamında, en fazla araştırılan konulardan biri iyi oluş (wellbeing) kavramıdır. Aslında iyi oluş kavramı, genel olarak "optimal psikolojik deneyim" ve "işlevsellik" (Deci ve Ryan, 2008, s. 1) olarak tanımlanmakla birlikte, içinde psikolojik sağlık, kaliteli yaşam, olumlu duygular ve yaşamdan alınan doyum gibi pek çok olumlu öğeyi barındıran "șemsiye" bir kavramdır (Diener, 1984; Myers ve Diener, 1995). Öznel iyi oluş, bilișsel yani yașamdan alınan doyum derecesi ile duygusal yani olumlu duyguların sıklığı ve olumsuz duyguların azlık derecesi bileșenlerden oluşur ve çoğu kaynakta mutluluk ile eș anlamlı kullanılır (Diener, 1984, 2000; Diener, Oishi ve Lucas, 2003). Bireyden uzun vadede yaşamından aldığı doyumu gözden geçirmesi ve ne sıklıkla olumlu ve olumsuz duygulanım deneyimlediğini özbildirim yoluyla değerlendirmesi istenir (Diener, 2000; Diener, Emmons, Larsen ve Griffin, 1985). Olumlu duygulanım, ilgi, gurur, heyecan, ilham, neșe ve aktif olmak gibi, olumsuz duygulanım ise öfke, düşmanlık, utanma, suçluluk ve korku gibi duyguları içerir. Pek çok çalışma, öznel iyi oluşu oluşturan bu üç yapıyı desteklemiştir (Diener, 2000; Lucas, Diener ve Suh, 1996). Bugüne dek araștırmalar, eğitim, yaș, cinsiyet, ekonomik gelir, medeni durum, dindarlık ve hatta zeka gibi sosyodemografik değişkenlerle öznel iyi oluşu çok az ilişkilendirmekte ya da hiç ilişkilendirememektedir (bk., Diener ve Ryan, 2009; Myers ve Diener, 1995). Genelde kişilik özellikleri, öznel iyi oluşun büyük bir varyansını (\%40-50) açılamaktadır (Diener ve ark., 1999; Lucas ve ark., 1996). Türkiye'de öznel iyi oluş konusu, pek çok farklı örneklem ve değișken ile uzun süredir çalıșılmaktadır (bk., Yalçın, 2015). Son yıllardaki araștımalar, öznel iyi oluş ile benlik saygısı (Doğan \& Eryılmaz, 2013; Eryılmaz \& Hasan, 2014; Tagay \& Baltacl, 2017; Türkmen, 2012); çeşitli kişilik özellikleri (Doğan, 2012; Eryılmaz ve Ercan, 2010; Eryılmaz ve Öğ̈̈lmüș, 2010), iyimserlik (Çağ \& Yıldırım, 2018; Eryılmaz, 2011; Öztürk, 2011; Tagay \& Baltacl, 2017; Yalçın, 2011), umut (Çankaya \& Meydan, 2018; Mercan, 2019; Sağkal \& Türnüklü, 2017); dini inanç ve bilişsel esneklik düzeyleri (Satan, 2014); çeşitli bağımlılıklar (Atak, 2011; Derin \& Bilge, 2016), minnettarlık (Duran \& Şeref, 2013); merhamet duygusu (İşgör, 2017); öz-anlayıș (Deniz, Arslan, Özyeşil, ve İzmirli, 2012) ve yalnızlık (Yılmaz ve Altınok, 2009; Yurcu, G., Kocakula, 2015) arasında ilişki kurmaktadır.

Öznel iyi oluşla ilişkili olabilecek değişkenlerden biri de yaşamda anlam deneyimidir. Kuşkusuz, yaşamda anlam denilince, en önce varoluşsal psikiyatrist Victor E. Frankl (1959/1985) akla gelir. Frankl'a göre, insanın en temel güdüsü anlam oluşturma ihtiyacıdır. Yaşamdaki gizli, derin ve kişisel anlamları, her insan hayatının belli dönemlerinde, öznel olarak kendisi keşfedebilmelidir. Bu ihtiyaç sürekli olup, cinsiyet, yaş, bilişsel beceri, kişilik özellikleri ya da dinsel görüşten bağımsızdır. Çünkü Frankl'a göre, özünde herkesin, yaşamsal bir nedene ihtiyacı vardır. Frankl'a (1985) göre, anlam üç kaynak yoluyla elde edilebilir. Bunlar; (1) acı çekmek (2) sevmek (3) üretmek, yaratmak ve çalışmaktır. Bu üç değere sahip olan insanlar, hayatlarında daha derin anlama sahiptirler. Öte yandan anlamsızlık, kişiyi derin buhranlara götürür ve hatta fiziksel ölüme bile itebilir. İnsanın en büyük varoluş amacı, kendisine bahşedilen gizli anlamları keşfetmesidir. Hatta en büyük acılarda ve travmatik süreçlerde bile, kişilerin bu deneyimlerinden gizli anlamları bulabilmesi beklenir. Bir diğer yaşamda anlam çalışan 
kuramcı olan sosyal psikolog Baumeister'e (1991) göre, Frankl'ın tersine, herkesin anlam bulmaya ya da oluşturmaya ihtiyacı yoktur. Bu temel ve evrensel bir ihtiyaç olmadığı gibi zaten yaşamın içinde de genel ve derin anlamlar bulunmaz. Yaşamda anlam iddiası taşıyan az sayıda kişi ise anlamı, bireysel bazda, kendisi oluşturmalıdır. Bu bireysel anlamlar, kişinin içinde bulunduğu kültürel değerlerin sunduğu olanaklarla gerçekleşir. Bu olanaklar, amaç, değer, özyeterlik ve özdeğer içermelidir (bk., Baumeister, 1991; Dursun \& Alyağut, 2020). İyilik hali ve iyi oluş alanyazınında, anlamlı bir yaşama sahip olmak, Aristoteles'in ödomonik (eudaimonia) kavramıyla ilişkilendirilmiştir. Bu kavram, ilk kez Ryff' in (1989) "psikolojik iyi oluş" modelinde ele alınmış ve kişinin potansiyelini gerçekleştirebilmesi olarak tanımlanmıştır. Ryff'e (1989) göre, psikolojik iyi oluş, bireyin yaşamı üzerinde kontrol elde etmesi, uzun süreli anlamlı ilişkiler kurabilmesi ve bir amaç doğrultusunda kendi fitratına ya da doğasına uygun bir yaşam tarzı edinmesi ile sağlanabilir. Yani, anlamlı bir yaşam, psikolojik iyi oluşun kaçınılmaz bir parçasıdır. Benzer şekilde, Ryan ve Deci (2000) tarafından "Öz-Belirleme" Kuramında, anlamlı yaşam, özellikle bireyin özerk ya da bağımsız kararlar alabilmesi ile ilișkilendirilmiștir. Özerklik ihtiyacı ile bireyler, yaşamları için en doğru kararları alarak, erdemli bir yaşam inşa edebilirler. Yeterlilik ve ilişkili olma gibi diğer psikolojik ihtiyaçlar doyurulduğunda, kişi, psikolojik açıdan büyümüş olur, gelişimini tamamlar ve böylece ödomonik bir yaşama sahip olur. Pozitif psikoloji kapsamında, Seligman (2002) "Otantik Mutluluk" kuramında, psikolojik/ödomonik ve öznel iyi oluş/hedonistik kavramlarını bir araya getirmiştir. O'na göre, dolu ya da tam bir iyi oluş, üç bileșenden oluşur. Bunlar; keyifli bir yaşam, yaşama bağlılık ve anlamın varlığıdır. Birbirini tamamlayan bu üç yol, en fazla yaşam tatminini getirecektir. Schueller ve Seligman (2010) göre anlam, bireyin kendine bir misyon yüklemesi, kendinden ulvi bir varoluşa ait hissetmesi ve bir amaca hizmet ettiğini hissetmesi olarak tanımlanmaktadır. Steger'in (2012) "Anlam Oluşturma" modeline göre ise, yaşamda anlam sahibi olmak, yaşamın bilişsel açıdan bireye anlamlı gelmesi ile bireyin yașamında genel bir hedefinin, ulvi bir amacının olduğuna inanması ve dinsel ya da inanç sisteminden kaynağını alan bir anlam dünyası dışında, bireyin her sabah uyanmak için kendisine söylediği bir nedeninin bulunması olarak tanımlanmaktadır (bk., Martela ve Steger, 2016). Son yıllarda gerçekleştirilen tüm anlamla ilgili çalışmalara göre, yaşamda anlam sahibi olmanın, psikolojik sağlık ve öznel iyi oluş ile olumlu yönde ilişkisi ve stresle başa çlkmada ise koruyucu bir etkisi olduğu ortaya çıkmıştır (Park, 2010; Steger ve Frazier, 2005; Steger, Frazier, Oishi ve Kaler, 2006; Steger ve Kashdan, 2007; Steger, Oishi ve Kashdan, 2009; Steger, Owens ve Park, 2015). Anlam arayışının ise, zorlayıcı bir durum ya da travmatik bir olayla karşılaşıldığında, olayı nedenselleştirme ve anlamlandırma sürecinde daha fazla rol oynadığı belirlenmiștir (Dursun, Steger, Bentele ve Schulenberg, 2016; Schulenberg, Strack ve Buchanan, 2011). Her ne kadar, alanyazında anlam araştırmaları, durumsal-genel durumluk-süreklik ya da bilişsel-duygusal gibi sınıflandırma tartışmaları içerse de (bk., Park, 2010), bu çalışmada, anlam deneyimi, bilișsel, genel ve sürekli bir kişilik özelliği olarak ele alınmıș ve öznel iyi oluş ile ilișkisi incelenmek istenmiștir.

Anlam sahibi olmaya benzer bir şekilde, umut da zorluklar karşısında kullanılan en güçlü psikososyal kaynaklardan biridir. Pozitif psikoloji yazınında umut, salt bir duygu olmayıp, güdüsel ve bilişsel altboyutları olan, etkileşimli ve karmaşık bir süreç olarak tanımlanır (Snyder, 2002). Umut düzeyi düşük olan bireyler, gerçekçi olmayan hedefler koyar, ardından doğal olarak başarısızlığa uğrar ve yaşanan hayal kırıklığı sonucunda daha fazla umutsuzluk sergiler ve başa çıkmakta yetersiz kalırlar (Snyder, Feldman, Taylor, Schroeder ve Adams, 2000). Pek çok çalışma, umut düzeyi yüksek olan bireylerin, spor ve akademik yaşantı gibi yaşamın farklı alanlarında daha fazla başarı elde ettiklerini (Curry, Snyder, Cook, Ruby ve Rehn, 1997; Snyder ve ark., 2002), fiziksel ve psikolojik yönden daha sağlıklı olduklarını (Barnum, Snyder, Rapoff, Mani ve Thompson, 1998; 
Green, Oades ve Grant, 2006) ve daha fazla olumlu duygu deneyimlediklerini ortaya çıkarmıştır (Chang ve Banks, 2007; Gallagher ve Lopez, 2009; Irving, Snyder, ve Crowson, 1998).

Umutla benzer işlev gösteren değişkenlerden biri de iyimserliktir. İyimserlik, gelecekte iyi şeylerin olacağına dair genel bir beklenti, his ya da inanç olarak tanımlanmaktadır (Scheier ve Carver, 1985). Araştırmalar, umut ile iyimserliğin kuramsal açıdan ilişkili, ancak ayrı yapılar olduğunu tespit etmiştir (Akçay, 2012; Gallagher ve Lopez, 2009; Fincan, 2019; Ho, Rajandram, Chan, Samman ve McGrath, 2011; Kulu, 2019; Shorey, Little, Snyder, Kluck ve Robitschek, 2007; Wong ve Lim, 2009). Psikolojik açıdan daha sağlıklı olan iyimserler, önlerine daha gerçekçi ve ulaşılabilir hedefler koyar, bu hedeflere ulaşırken daha çok çaba sarfeder ve sonunda amaçlarını gerçekleştirmede daha başarılı olurlar (Carver, Scheier ve Segerstrom, 2010; Segerstrom, 2007; Solberg Nes ve Segerstrom, 2006). İyimserlik ve öznel iyi oluş belirleyicilerinden biri olan yaşam doyumu arasında olumlu yönde bir ilişki mevcuttur (Ben-Zur, 2003; Eryılmaz, 2011; Kümbül Güler ve Emeç 2006; Utsey, Hook, Fischer ve Belvet, 2008).

\section{Araștırmanın Amacı}

Anlamlı bir yaşam deneyimi, geleceğe iyimser bir pencereden bakabilmek ve gerçekçi bir hedefe doğru yılmadan ilerlemek, öznel iyi oluşa olumlu yönde katkıda bulunacaktır. Nitekim, pek çok araştırma, yaşamında anlam olduğunu belirten bireylerin hayattan daha fazla doyum aldıklarını, daha fazla olumlu duygulanım yaşadıklarını, daha iyimser ve fiziksel açıdan daha sağlıklı olduklarını ve kendilerine daha fazla güvendiklerini ortaya koymaktadır (örn., Dogra, Basu ve Das, 2011; Park, Park ve Peterson, 2010). Benzer şekilde, iyimserlik, umut ve öznel iyi oluş da olumlu yönde ilişkilidir (örn. Daukantaite ve Zukauskiene, 2012; Irving ve ark., 1998; Wong ve Lim, 2009). Ancak Türk alanyazınında, bu üç değişkenin bir arada kullanıldığı bir araştırma deseni bulunmamaktadır. Bu bağlamda, bu araștırmadaki amacımız, öznel iyi oluş üzerindeki tüm bu değişkenlerin ayrı ayrı yordayıcı katkılarını bir model çerçevesinde test etmektir. Bu amaçla, bağımsız değişken olarak alınan yaşamda anlam sahibi olma, iyimserlik ve umut puanlarının birbirleriyle olumlu yönde ilişkili olacağı ve öznel iyi oluş kavramını olumlu yönde yordayacağı, yaşamda anlam arayışının ise öznel iyi oluşu olumsuz yönde yordayacağı beklenmektedir.

\section{Yöntem}

\section{1. Çalışma Grubu}

Araştırmaya tesadüfi (convenient) örneklem yoluyla Afyon Kocatepe Üniversitesi'nin beș ayrı fakültesinde (İktisadi ve İdari Bilimler, Mühendislik, FenEdebiyat, Eğitim ve Sağlık Bilimleri Fakültesi) öğrenim gören 1160 öğrenci katılmıştır. Ancak eksik verilerin ve aykırı değerlerin veri setinden silinmesi sonucunda 984 (582 kadın ve 402 erkek) katılımcı ile istatistiksel analiz tamamlanmıştır. Katılımcıların yaşları 18-30 arasında değişmekte olup, ortalama 21.26 (SS =1.69)'dır. Genel olarak katılımcılar, İktisadi ve İdari Bilimler Fakültesinde 123 (87 kız, 36 erkek) öğrenci, Eğitim Fakültesinde 282 (198 kadın ve 84 erkek) öğrenci, Mühendislik Fakültesinde 205 (61 kadın ve 144 erkek) öğrenci bulunmaktadır, Fen Edebiyat Fakültesi'nde 283 (174 kadın ve 109 erkek) ve Sağlık Bilimleri Fakültesinden 91 (62 kadın ve 29 erkek) öğrenciden oluşmaktadır. Afyon Kocatepe Üniversitesi'nden ve Orta Doğu Teknik Üniversitesi'nden etik izinler alınarak çalışma yürütülmüştür. Anketler, belirtilen beş fakültede öğrencilerin okul günlerinde sınıflarında gönüllü olarak uygulanmış olup toplam 20 dakika sürmüștür. 


\subsection{Veri Toplama Araçları}

Veri toplama araçları olarak, Sosyo-demografik Bilgi Formu, Yaşamın Anlamı Anketi, Yaşam Yönelimi Testi, Umut Ölçeği ve Öznel İyi Oluşu ölçmek üzere OlumluOlumsuz Duygu Ölçeği ile Yaşam Doyumu Ölçeği kullanılmıştır.

\subsubsection{Sosyo-Demografik Bilgi Formu}

Öğrencilerin yaş, okul, sınıf ve genel not ortalamalarını içeren yazarlarca oluşturulmuş bir bilgi formudur.

\subsubsection{Yaşamın Anlamı Anketi}

Yaşamın Anlamı Anketi (Meaning in life Questionnaire), Steger ve ark. (2006) tarafından geliștirilmiş, algılanan yaşam anlamı düzeyi ve anlam arayıșı sürecini ölçmeyi amaçlayan bireyin kendi yanıtladığı " 1 = kesinlikle doğru değil" ile " $7=$ kesinlikle doğru" arasında cevaplanan 7'li Likert tarzı derecelendirme anketidir. Toplam 10 maddeden ve iki alt boyuttan oluşmaktadır. Bu alt boyutlar anlamın varlığı (presence of meaning), anlam arayışı (search for meaning) olup her bir alt boyut beş maddeden oluşmaktadır. Cronbach alfa iç tutarlılık katsayısı anlamın varlığı alt boyutu için .82-.87, anlam arayışı alt boyutu için .86 -.87 arasında değişmektedir (Steger ve ark., 2006). Türkçe uyarlama çalışması, araştırmacı tarafından bu araştırmanın ilk aşaması olarak gerçekleştirilmiștir (Dursun, 2012). Yapı geçerliliği için gerçekleștirilen açıklayıcı faktör analizi ve doğrulayıcı faktör analizi ile ölçek, orjinal ölçeğe benzer şekilde, iki alt boyutlu olarak saptanmıştır. Toplam varyansın \%56.57 açıklamaktadır. Ölçüt geçerliği bakımından, Rosenberg Benlik Saygısı Ölçeği, Genel Sağlı Anketi ve Beş Faktör Kișilik Envanteri ile Sosyal Beğenirlik/İstenirlik Ölçeği kullanılmıştır. Anlamın Varlığı, nevrotiklik dışında kișilik envanterinin tüm alt boyutlarıyla (23 ile .27 arasında) ve benlik saygısı $(r=.26)$ ile olumlu, psikolojik sorunlarla ise olumsuz ilișkiliyken ( $\mathrm{r}=-.31$ ), Anlam Arayıșı alt boyutu ise nevrotiklik $(\mathrm{r}=.24)$ ve psikolojik sorunlarla olumlu $(\mathrm{r}=.23)$, uzlaşmacıllk kişilik özelliği ile ise olumsuz ilişkili ( $\mathrm{r}=-.24$ ) olduğu saptanmıștır. Her iki alt boyutun sosyal beğenirlik ile anlamlı bir ilişkisi bulunmamaktadır. Cronbach alfa iç tutarlılık katsayısı anlamın varlığı alt boyutu için .83, anlam arayışı alt boyutu için .87 olarak bulunmuştur. Test tekrar-test güvenirlik katsayıları anlamın varlığı alt ölçeği için .84, anlam arayışı için .81 olarak hesaplanmıştır. Bu araștırmada ise iç tutarlılık katsayıları anlamın varlığı alt boyutu için .79, anlam arayışı alt boyutu için ise .88 olarak belirlenmiştir.

\subsubsection{Yaşam Yönelimi Testi}

Yaşam Yönelimi Testi (Life Orientation Test), Scheier ve Carver (1985) tarafından geliştirilmiş bireyin iyimserlik düzeyini ölçmeyi amaçlayan dört tanesi toplam puana dahil edilmeyen, 12 maddelik, " 0 = tamamen katılmıyorum" ile " 4 = tamamen katılıyorum" arasında cevaplanan 5'li Likert tarzı derecelendirme ölçeğidir. Alınan puanlar, 0-32 arasında değişmekte olup, yüksek puanlar yüksek iyimserlik düzeyi anlamına gelmektedir. Cronbach alfa iç tutarlılık katsayısı .84 olarak bulunmuştur (Scheier ve Carver, 1985). Türkçe uyarlama çalışmaları Aydın ve Tezer (1991) tarafından gerçekleștirilmiş, Cronbach alfa iç tutarlılık katsayısı .72 ve test tekrar-test güvenirlik katsayısı .77 olarak rapor edilmiş, yaygın kullanılan güvenilir ve geçerli ölçeklerden biridir. Bu çalışmada, Cronbach alfa iç tutarlılık katsayısı .70 olarak hesaplanmıştır. 


\subsubsection{Umut Ölçeği}

Umut Ölçeği (Hope Scale), umut düzeyinin belirlenmesi amacıyla Snyder ve ark. (1991) tarafından geliștirilmiștir. Dört sorunun toplam puana dahil edilmediği toplam 12 maddelik, " 1 = tamamen katılmıyorum" ile " $4=$ tamamen katılıyorum" arasında cevaplanan 4'lü Likert tarzı derecelendirme ölçeğidir. Alınan puanlar 8-32 arasında değişmekte olup, yüksek puanlar yüksek umut düzeyi anlamına gelmektedir. Cronbach alfa iç tutarlılık katsayısı tüm ölçek için .71- .76, arasında değişmektedir (Snyder ve ark., 1991). Ölçeğin Türkçe uyarlaması Akman ve Korkut (1993) tarafından gerçekleştirilmiş ve Cronbach alfa iç tutarlık katsayısı toplam ölçek için .65 ve test-tekrar test güvenirliği .66 olarak rapor edilmiştir. Bu çalışmada, Cronbach alfa iç tutarlılık katsayısı toplam umut puanı için .77'dir.

\subsubsection{Olumlu-Olumsuz Duygu Ölçeği}

Olumlu-Olumsuz Duygu Ölçeği (Positive and Negative Affect Scale) bireylerin ne sıklıkla olumlu ve olumsuz duygulanım yaşadığını ölçmek amacıyla Watson, Clark ve Tellegen (1988) tarafından geliştirilmiş, iki alt boyutu 10 maddeden oluşan 20 maddelik "1 = asla" ile " 5 = daima" arasında puanlanması gereken 5'li Likert tipi derecelendirme ölçeğidir. Cronbach alfa iç tutarlılık katsayıları olumlu duygu için .86-.90 arasında, olumsuz duygu için .84-.87 arasında değişmektedir (Watson ve ark., 1988). Türkçe uyarlamasını Gençöz (2000) gerçekleştirmiş, Cronbach alfa iç tutarlık katsayıları olumlu duygu için .83, olumsuz duygu için .86 olarak rapor etmiştir. Şimşek (2005) ve Kankotan (2008) geçerlilik ve güvenirlik analizini gerçekleștirdikleri çalıșmalarında 7'li derecelendirme tipini kullanmış ve tatmin edici psikometrik özellikler bildirmişlerdir. $\mathrm{Bu}$ çalışmada, benzer şekilde 7'li derecelendirme tipi kullanılmış ve Cronbach alfa iç tutarlık katsayıları olumlu duygu için .76, olumsuz duygu için .65 olarak hesaplanmıştır.

\subsubsection{Yaşam Doyumu Ölçeği}

Yaşam Doyumu Ölçeği (Life Satisfaction Scale), Diener ve ark. (1985) tarafından geliştirilen bu ölçek, bireylerin yaşamlarından aldıkları doyumu öznel olarak değerlendirmelerini amaçlar. 5 maddeden oluşan " 1 = tamamen katılmıyorum" ile " 5 = tamamen katılıyorum” arasında cevaplanan 5'li Likert tipi derecelendirme ölçeğidir. Beş maddelik ölçeğin iç tutarlık katsayısı .82 olarak rapor edilmiştir (Diener ve ark., 1985). Ölçeğin Türkçe'ye uyarlanması Köker (1991) tarafından gerçekleștirilmiş olup Cronbach alfa iç tutarlık katsayısı .89 olarak saptanmış ve test-tekrar test güvenirliği .85 olarak rapor edilmiștir. Bu çalışmada, Cronbach alfa katsayısı .77 olarak hesaplanmıştır.

\subsection{Verilerin Analizi}

Çalışmanın amacı doğrultusunda, tüm değişkenler (yaşamın anlamı altboyutları, iyimserlik, umut ve öznel iyi oluş) arasında ilişkiyi saptamak için ise Pearson Momentler Çarpımı Korelasyon Analizi kullanılmıştır. Araştırmada elde edilen veriler SPSS-18 programı kullanılarak analiz edilmiștir. Yașamın Anlamı altboyutları, iyimserlik, umut puanlarının öznel iyi oluş kavramını açılama düzeyini belirleyebilmek amacıyla ise Yapısal Eşitlik Modeli (YEM) (EQS, Bentler, 2004) uygulanmıştır. 


\section{Bulgular}

Tablo 1'de görüldüğü üzere, öznel iyi oluş bileşenleri olan olumlu duygunun ortalaması $51.32(S S=7.55)$, olumsuz duygunun ortalaması $31.16(S S=7.70)$ ve yaşam doyumu ortalaması ise $16.71(S S=4.00)$ olarak hesaplanmıştır. Pearson Momentler Çarpımı Korelasyon analiz sonuçlarına göre, olumlu duygu, olumsuz duygu ile olumsuz yönde $(r=-.13, p<.01)$ ve yaşam doyumu ile olumlu yönde $(r=.28, p<.01)$ ilişkilidir. Olumlu duygu, yaşamda anlam duygusu $(r=.23, p<.01)$, iyimserlik $(r=.26, p<.01)$ ve umut $(r=.53, p<.01)$ ile olumlu yönde ilişkilidir ve yaşamda anlam arayışı ile ise anlamlı bir iliş̧isi yoktur. Olumsuz duygu, yaşam doyumu $(r=-.24, p<.01)$, yaşamda anlam sahibi olma $(r=-.19, p<.01)$, iyimserlik $(r=-.38, p<.01)$ ve umut düzeyi $(r=-.27, p<.01)$ ile olumsuz yönde, anlam sorgulayışı ile ise $(r=.17, p<.01)$ olumlu yönde ilișkilidir. Benzer şekilde, yaşam doyumu, yaşamda anlam sahibi olma $(r=.35, p<.01)$, iyimserlik $(r=.41, p$ $<.01)$ ve umut düzeyi $(r=.37, p<.01)$ ile olumlu yönde, anlam sorgulayışı ile ise $(r=-.21$, $\mathrm{p}<.01$ ) olumsuz yönde ilişkilidir. Cohen d (1992) kriterlerine göre, korelasyon katsayılarının hemen hemen hepsi, düşük (0.1) ya da orta (0.3) ile büyük etki büyüklüğü arasında değişmektedir.

Tablo 1: Betimleyici İstatistik ve Korelasyon matriksi

\begin{tabular}{|c|c|c|c|c|c|c|c|}
\hline Veri Araçları & 1 & 2 & 3 & 4 & 5 & 6 & 7 \\
\hline 1. Olumlu Duygu & 1 & $-.13^{* *}$ & $.28^{* *}$ & $.23^{* *}$ & -.04 & $.26^{* *}$ & $.53^{* *}$ \\
\hline P değeri & & .000 & .000 & .000 & .232 & .000 & .000 \\
\hline 2. Olumsuz Duygu & & 1 & $-.24^{* *}$ & $-.19^{* *}$ & $.17^{* *}$ & $-.38^{* *}$ & $-.27^{* *}$ \\
\hline P değeri & & & .000 & .000 & .000 & .000 & .000 \\
\hline 3. Yaşam Doyumu & & & 1 & $.35^{* *}$ & $-.21^{* *}$ & $.41^{* *}$ & $.37^{* *}$ \\
\hline 4. Anlam Varlığı & & & & 1 & $-.33^{* *}$ & $.32^{* *}$ & $.37^{* *}$ \\
\hline P değeri & & & & & .000 & .000 & .000 \\
\hline 5. Anlam Arayıșı & & & & & 1 & $-16^{* *}$ & $-.11^{* *}$ \\
\hline P değeri & & & & & & .000 & .001 \\
\hline 6. İyimserlik & & & & & & 1 & $.43^{* *}$ \\
\hline P değeri & & & & & & & .000 \\
\hline 7. Umut & & & & & & & 1 \\
\hline Ortalama & 51.32 & 31.16 & 16.71 & 27.22 & 20.18 & 19.82 & 26.31 \\
\hline SS & 7.55 & 7.70 & 4.00 & 5.93 & 8.48 & 4.93 & 3.34 \\
\hline Min.-max. değer aralıkları & $10-70$ & $10-70$ & $5-25$ & $5-35$ & $5-35$ & $0-32$ & $8-32$ \\
\hline
\end{tabular}

\section{Modellenmesi \\ 4.1 Öznel İyi-Oluşun Yordayıcılarının Yapısal Eşitlik Analizi ile}

Bu araştırmada, yaşamda anlam sahibi olmak, iyimserlik ve umudun birbirleriyle olumlu yönde ilişkili olması ve öznel iyi oluş kavramını olumlu yönde yordaması; yaşamda anlam arayışının ise tüm değişkenlerle olumsuz yönde ilişkili olması ve öznel iyi oluş kavramını olumsuz yönde yordaması beklenmektedir. Bu nedenle, bu değișkenlerle bir model oluşturulması, olası doğrudan ve dolaylı etkiler ile bu modelin sınanması için geleneksel regresyon analizlerinin devamı sayılabilecek Yapısal Eşitlik Modelleri (YEM) uygulanmıştır (bk., Sümer, 2000; Şimşek, 2007). EQS programı (Bentler, 2004) ile gerçekleştirilen modelde yer alan değişkenler arasındaki korelasyonlar, Tablo 1'de gösterilmiștir. Modelin yapılandırılmasında Kovaryans Matrisleri ve en Maksimum Olabilirlik Tahmini Yöntemi kullanılmıștır. Modellerin veriye uyumu temel olarak Ki-kare $\left(\chi^{2}\right)$ Uyum İyiliği Testi (ChiSquare Goodness of Fit), Uyum İyiliği İndeksleri (Goodness of Fit) ve Karşılaştırmalı Uyum İndeksleri'ne (Comparative Fit Indices ) dayanmaktadır (bk., 
Byrne, 2001; Hu ve Bentler, 1999; Schumacker ve Lomax, 1996).Yapısal eşitlik modeli sinanmadan önce, gözlenen değişkenlerin gizil değişkenleri ne kadar iyi temsil ettiğini gözlemek için, yaşamda anlam ve öznel iyi oluş değişkenleri için ayrı ayrı ölçüm modelleri test edilmiştir. Ayrı ayrı gerçekleştirilen bu ölçüm modellerinin, herhangi bir düzeltmeye gereksinim duyulmadan, verilere iyi uyum sağladığı görülmüştür. $\chi 2$ değerleri örneklem büyüklüğüne duyarlı olduğu için genelde anlamlı çıkmakta ve bu nedenle $\chi^{2} /$ sd değeri daha fazla ön plandadır (Şimşek, 2007). Yaşamda anlam uyum indeksleri $\chi^{2}$ [34, N=984] $=155.92, \mathrm{p}<.001, \chi^{2} / \mathrm{sd}=4.58, \mathrm{GFI}=.97, \mathrm{AGFI}=.95, \mathrm{NNFI}=.96, \mathrm{CFI}=.97, \mathrm{RMSEA}=.06$, $90 \%-\mathrm{CI}=[0.051,0.070]$; öznel iyi oluş uyum indeksleri; $\chi^{2}[64, \mathrm{~N}=984]=376.25, \mathrm{p}<.001$, $\chi^{2} / \mathrm{sd}=5.87, \mathrm{GFI}=.95, \mathrm{AGFI}=.92, \mathrm{NNFI}=.91, \mathrm{CFI}=.93, \mathrm{RMSEA}=.07,90 \%-\mathrm{CI}=[0.064$, 0.077]. Yașamda anlam altboyutlarına ilişkin gizil değișken, ilgili maddelerce temsil edilmektedir (anlamın varlığı için faktör yükleri sırasıyla .62, .71, .79, .64, .57'dir; anlam arayışı için faktör yükleri sırasıyla $.74, .74, .80, .82, .78^{\prime}$ dir). Yaşamda anlam sahibi olmak ile yaşamda anlam arayıșı birbiriyleriyle olumsuz yönde ilişkilidirler ( $\mathrm{r}=-.38$ ) ve doğrulayıcı faktör analizi verilerine göre model uyumu orjinal ölçekteki faktör yapısına parallelik göstermiştir. Yaşamda anlam altboyutları ile birlikte gerçekleștirilen bir diğer ölçüm modelinde, öznel iyi oluş gizil değişkeni olumlu duygu (.38), olumsuz duygu (.36) ve yaşam doyumu (.54) göstergeleri ile temsil edilebilmekte ve model herhangi bir düzeltmeye gereksinim duyulmadan verilere iyi uyum sağlamaktadır. Ancak yașamda anlam altboyutları, tek bir ölçeğin alt yapıları olduğu için daha iyi uyum indekslerine sahipken, öznel iyi oluş yapısı daha yapay ya da sentez bir yapıdır. Bu bakımdan, yaşamda anlam alt boyutlarından daha az güçlü uyum indekslerine sahip olabilir. Üçüncü aşama olarak, yaşamda anlam altboyutları gizil değişken olarak, umut, iyimserlik ve olumlu duygu ile olumsuz duygu ve yaşam doyumu değişkenlerinin gösterge değișken olarak yer aldığı yapısal model test edilmiştir. Ne var ki önerilen bu modelin, örneklemden elde edilen veriler ile yeterince doğrulanamadığı görülmektedir $\left(\chi^{2}[88, \mathrm{~N}=984]=612.99, \mathrm{p}<\right.$ $.001, \chi^{2} / \mathrm{sd}=6.96, \mathrm{GFI}=.92, \mathrm{AGFI}=.89, \mathrm{NNFI}=.87, \mathrm{CFI}=.86, \mathrm{RMSEA}=.08,90 \%-\mathrm{CI}=$ $[0.072,0.084])$. Modifikasyon indeksleri incelendiğinde, Lagrange Multiplier (LM) düzeltme indeksi doğrultusunda, Yaşamın Anlamı Anketi'nin iki ayrı faktöründe yer alan, madde 6 (Doyurucu bir yaşam amacı keșfettim) ile madde 10 (Yaşamımın anlamını arıyorum) arasına bir hata kovaryasyonu eklenmiştir. Bu maddeler, anlam açısından birbirinin tersi olmakla birlikte benzer içeriktedirler. Kuramsal açıdan LM modifikasyonu, bir engel teşkil etmemektedir (bk., MacCallum, Roznowski ve Necowitz, 1992). Bu düzeltme sonucunda önerilen yeni modelde ki-kare sayısı, örneklem sayısına duyarlı olduğu için diğer uyum indekslerine odaklanılmıştır (Byrne, 2001; Schermelleh-Engel, Moosbrugger ve Müller, 2003). Şimşek'e (2007) göre, $\chi^{2}$ serbestlik derecesine bölünmesiyle elde edilen değerin 5 ya da altında olması, GFI, AGFI, CFI'nin .90 değerinin üzerinde olması ve RMSEA değerinin .08'in altında olması kabul edilebilir bir uyum iyiliğini göstermektedir. $\mathrm{Bu}$ bağlamda, yeni modelin kabul edilebilir düzeyde uyum istatistiklerine sahip olduğu $\left(\chi^{2}[87, \mathrm{~N}=984]=504.34, \mathrm{p}<.001, \chi^{2} / \mathrm{sd}=5.79, \mathrm{GFI}=.93\right.$, $\mathrm{AGFI}=.91, \mathrm{NNFI}=.90, \mathrm{CFI}=.92, \mathrm{RMSEA}=.07,90 \%-\mathrm{CI}=[0.064,0.076])$ ve bir önceki modelden daha iyi sonuçlar verdiği görülmektedir $\left(\Delta \chi^{2}=108, \Delta \mathrm{sd}=1, p<.001\right)$. Nitekim bu model, toplam varyansın \%65'ini açıklamaktadır. Şekil 1'de de gösterildiği gibi, yaşamda anlam sahibi $(\beta=.35, p<.05)$, umutlu $(\beta=.24, p<.05)$ ve iyimser olmanın $(\beta=$ $.65, p<.05)$ öznel iyi oluş üzerinde anlamll, olumlu ve doğrudan, yaşamda anlam arayıșının $(\beta=-.12, p<.05)$ ise olumsuz ve doğrudan ilișkili olduğu yapısal eșitlik modeli ile açıklanmaktadır. 


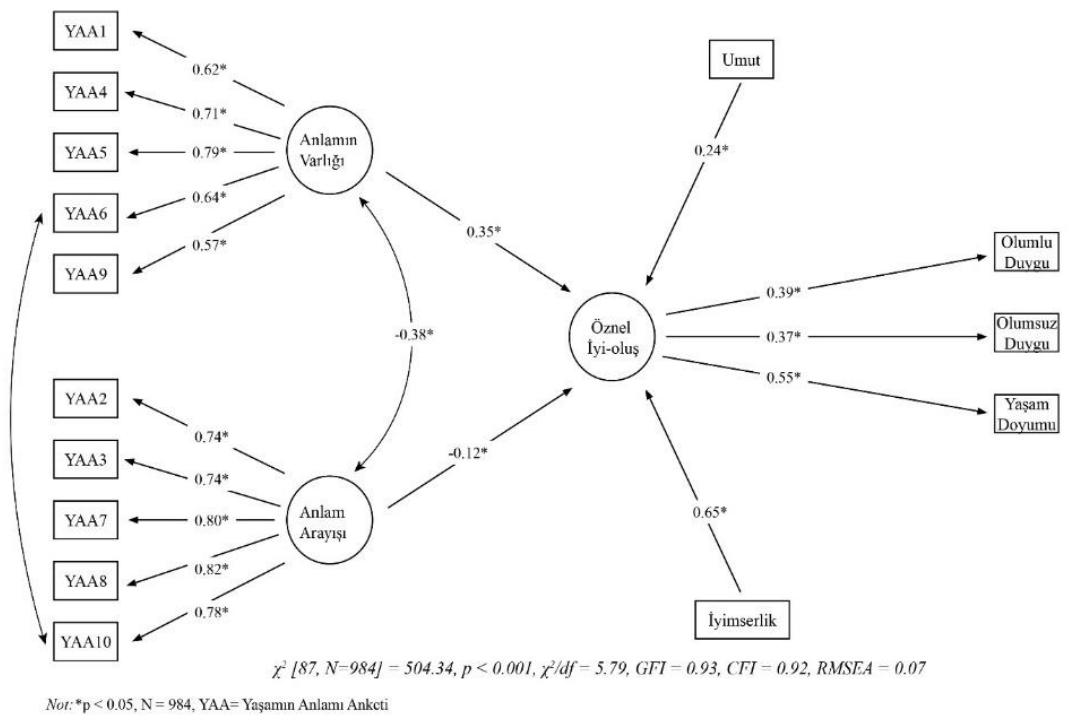

Şekil 1. Araștırma modeli

\section{Tartışma, Sonuç ve Öneriler}

Bu araştırma, yaşamda anlam sahibi olmak ve yaşamda anlam arayışında olmanın iyimserlik ile umut düzeylerinin, olumlu duygu, olumsuz duygu ve genel yaşam doyumu bileșenlerinden oluşan mutluluk kavramı ile ilişkisi ve yordamadaki katkı düzeyleri yapısal eşitlik modeli yoluyla incelemektedir. Öncelikle, gerçekleștirilen ölçüm modellerinden öznel iyi oluş kavramının üç bileșenle uygun temsil edilebildiği görülmüştür (bk., Şekil 1). Sonrasında yapılan YEM sonucunda, tüm değișkenlerin öznel iyi oluşu anlamlı olarak yordadığı görülmektedir, başka bir deyişle, yaşamlarında anlama sahip olan, iyimser ve umutlu bireylerin, daha yüksek öznel iyi oluş düzeyi sergiledikleri görülürken, anlam arayışında olan bireylerin, tam tersi daha düşük öznel iyi oluş düzeyine sahip oldukları söylenebilir. Her ne kadar Türk alanyazınında umut, iyimserlik ve anlam algısının birlikte yer aldığı bir araştırma olmasa da, ayrı ayrı ilişkilerin incelendiği çalışmalar, benzer sonuçları vermektedir (Örn., Ben-Zur, 2003; Chang ve Banks, 2007; Daukantaite ve Zukauskiene, 2012; Gallagher ve Lopez, 2009; Ho, Cheung ve Cheung, 2010; Irving ve ark., 1998).

Anlamlı yaşam, yaşamın bireye makul gelmesi, bir yön ve amaç duygusunun olması ve kişinin yaşanmaya değer bir hayatının olduğuna inanmasıdır (bk., Martela ve Steger, 2016). Birey, varolmasının dünyada bir nedeni, bir önemi ve bir değeri olduğunu düşünürse, yaşamından daha fazla doyum alır, daha fazla olumlu duygulanım yaşar başka bir deyişle daha mutlu olur. Bu bağlamda, araştırmamızdan elde edilen, öznel iyi oluş ve anlam sahibi olma arasındaki olumlu ilişki ilgili alanyazın ile tutarlıdır (örn., Herero ve Extremera, 2010; Ho ve ark., 2010; Ju, Shin, Kim, Hyun ve Park, 2013; Kashdan ve Steger, 2007; Park, 2010; Steger ve Frazier, 2005; Steger ve Kashdan, 2007; Steger ve ark., 2015). Anlam sorgulayıșı, genelde, anlam kaybına uğradığımız, bașımıza gelen olumsuz olayları 
"anlamlandırmaya" ve "gerekçelendirmeye" çalışırken ya da yaşamda yönümüzü yitirdiğimizde devreye girer. Anlam yaratma ya da oluşturma yoluyla olumsuz olaylarla başa çıkmayı öğreniriz (Park, 2010; Park ve Folkman, 1997). Bu araştırma sonucu ile paralel olarak, anlam arayıșı genel olarak sancılı ve acı verici bir süreçtir, bu nedenle öznel iyi oluş ile olumsuz yönde ilişkilidir (Ju ve ark. 2013, Park ve ark., 2010; Steger ve ark., 2008; Steger ve ark., 2010).

Bir diğer sonuç ise, iyimserlik ve umudun, öznel iyi oluşu olumlu bir şekilde yordadığı bulgusudur. Bu bulgu da alanyazın ile tutarlıdır (Busseri, Choma ve Sadava, 2009; Chang, 1998; Daukantaite ve Zukauskiene, 2012; Wong ve Lim, 2009). Hatta, iyimserliğin diğer değişkenlere göre en güçlü öznel iyi oluş yordayıcısı olduğu görülmektedir. Başka bir deyişle, iyimser bireyler, yaşamdan daha fazla doyum almakta ve daha sık olumlu duygulanım deneyimlemektedir. Çünkü, gelecekten olumlu şeyler beklemek, stresli olaylara karşı bir tür koruyucu kalkan görevi görmektedir. İyimser bireyler bir zorlukla karşılaştıklarında, bu zorlukları bir tehdit yerine meydan okuma gibi görürler ve aşabileceklerine olan inançları daha fazladır. Sosyal destek, yeniden yorumlama, olumlu çerçevelendirme gibi uygun ve esnek başa çıma stratejilerini daha fazla kullanırlar (Carver ve ark., 2010; Forgeard ve Seligman, 2012; Solberg Nes ve Segerstrom, 2006).

İyimserliğe benzer bir psikososyal kaynak olan umut, kısa süreli ya da uzun süreli uygun bir amaç belirleyip onu başarma arzusu ve planını kapsayan bir süreç olarak tariflenmektedir (Snyder ve ark., 1991). Bu bağlamda, öznel iyi oluşun anlamlı ve olumlu bir yordayıcısıdır (Irving ve ark. 2004; Kato ve Snyder, 2005; Resnick, Fontana, Lehman ve Rosenheck, 2005; Werner, 2012). Nitekim, araștırmamız da bunu desteklemektedir. İyimserliğe benzer şekilde, umut düzeyi yüksek bireyler, duygusal engellerin kendilerini engellemesine izin vermez ve sorunları çözerken, daha yapıcı ve esnek davranırlar. Ancak bu araştırmada, umut, iyimserlik kadar güçlü bir yordayıcı olarak bulunmamıștır. Bunun yöntemsel ve kavramsal nedenleri olabilir. Yöntemsel açıdan, analizlerde, altboyutlar yerine toplam umut puanının kullanılmış olması olabilir. Kavramsal açıdan ise, umudun, iyimserliğe göre daha fazla bilişsel içerikli bir yapı olması olabilir (Gallagher ve Lopez, 2009; Kato ve Snyder, 2005, Tarhan ve Bacanll, 2015). İyimserlik, bireyin sadece gelecekten iyi şeyler beklemesi, iyi șeyler olacağına inancı ya da hissidir. Ancak bu beklenti, inanç ya da hissin kaynağı, şans, kader ya da maneviyat olabilir (Alarcon, Bowling ve Khazon, 2013). Bu açıdan, en azından bizim örneklemimizdeki katılımcılar, öznel iyi oluşu inanç ya da duygu ağırlıklı iyimserlik kavramı ile daha fazla ilișkilendirmektedir. Bunun olası nedeni, katılımcıların, akılcı bir hedef koyma ve buna ulaşmak için uygun ve etkili bir plan yapma gibi bilişsel haritaları daha az düzeyde kullanmaları sayılabilir.

Bu araştırmanın sınırlılıklarına gelince, odağımız gereği, kavramsal model tek bir model ile test edilmiştir, gelecek araștırmalarda değişkenlerin rolleri alternatif modeller ile test edilebilir. Örneğin, yaşamda anlam kavramı üzerindeki katkı rolleri, farklı değişkenler eklenerek test edilebilir. Her ne kadar, kavramsal model, yapısal eșitlik modeli ile incelense de, araştırmanın kesitsel olmasından dolayı ilişkiler korelasyonel düzeydedir ve gerçek neden-sonuç ilişkileri kurulamamıştır. Araştırmanın bir diğer kısıtlılığı, verilerin yalnızca özbildirim ölçeklerine dayanmasıdır. Özellikle anlam arayışı ve yeniden yapılandırma süreci, kayıplar ve stresli durumlar ile ilişkili olduğu için anlam kavramı nitel görüşmelerle daha bütünlüklü ele alınabilir (bk., Park, 2010; Wortmann ve Park, 2009). Aynı zamanda, yine anlam algısı yaş ile ilişkili olduğu için üniversite öğrencileri yerine daha farklı yaş gruplarıyla çalışmalar yürütülebilir (bk., Reker, 2005; Steger ve ark., 2009).

Sonuç olarak, insanı var eden erdemlerin daha fazla anlaşılması gerektiğini savunan pozitif psikoloji ile öznel iyi oluş, anlam, iyimserlik ve umut gibi kavramlar, en 
fazla odaklanılan araştırma konuları haline gelmiştir. Son yıllarda gelecek karşısında gerçekçi yargıları olan bireylerin daha önleyici ve koruyucu tutum ve davranışları benimsediği (Snyder ve ark., 2000) ve stresli durumlar için daha fazla ekonomik ve psikososyal kaynaklara sahip olduğu (Segerstrom, 2007) bilinmektedir. Ancak, iyimser ve umutlu bireylerin daha mı fazla kaynak biriktirdikleri yoksa kaynak biriktirmenin kendisinin mi bireyi umutlu ve iyimser yaptığı konusu halen bilinmemektedir. Bilinen şu ki, yaşamında anlamlı bir amacı, yönü ve önemi olduğunu düşünen, bu amaca ulaşmak için uygun yöntemler benimseyen, yllmayan, kendini motive eden, kendine inanan iyimser ve umutlu bireyler, iyi oluş düzeyi daha yüksek bireylerdir. Bu çalışmadan hareketle, özellikle üniversite öğrencileriyle çalışan klinisyen ya da danışmanların, öznel iyi oluş düzeyini artırmaları için, iyimserlik, umut ve anlamlı bir yaşam vurgusu yapmaları uygun olacaktır. Gelecekten iyi şeyler beklerken, gerçekçi hedefler koymak ve bunlara ulaşmak için akılcı planlar yapmak engellerin daha kolay aşılmasına neden olacaktır. Yaşamında yönü, amacı olan kişilerin yani anlama sahip olanların, umutlu ve iyimser oldukları ve tüm bu özelliklerin öznel iyi oluşa katkıda bulunduğu bulgusu ile koruyucu ve önleyici çalışmalar gerek seminerler ve çalışma gruplarında, gerekse bireysel danışmanlıklarla gerçekleștirilebilir. Aynı zamanda, yaşamda anlam elde etmenin yolları ve kaynakları, danışanlarla birlikte keşfedilebilir. Her ne kadar bu araștırma, anlam kaynakları elde etme odaklı olmasa da, her anlamın öznel olduğu ve acılardan da anlam çıkarabileceği bilgisi ile danışanlarla kişisel bir yolculuk gerçekleştirilebilir. Elbette, pek çok danışanın içinde bulunduğu özellikle depresif içerikli bilişsel çarpıtmalarla, hayata iyimser ve umutlu bakabilmek çok zordur. Ancak, bu bilişsel çarpıtmaların gölgesinde bile danışanların hayatlarında anlamlı buldukları ve anlamlı kılmasına zemin hazırlayan amaç, değer ve önem atfedilen konular keşfedilebilir. Sonuç olarak, bu araştırma ile olumlu duygu, olumsuz duygu ve yaşam doyumu ile karakterize öznel iyi oluş algısının, yaşamda anlam sahibi olma, iyimser ve umutlu olma ile ilişkili olduğu ve hatta en güçlü yordayıcının ise iyimserlik olduğu tespit edilmiştir. Öznel iyi oluşun inşası, anlamın oluşturulduğu bir yaşamla, iyimser ve umutlu bir bakış açısı ile mümkün görünmektedir.

\section{KAYNAKÇA}

AKÇAY, V. H. (2012). Pozitif psikolojik sermayenin iş tatmini ile ilişkisi. Kahramanmaraş Sütçü İmam Üniversitesi İktisadi ve İdari Bilimler Fakültesi Dergisi, 2(1), 123-140.

AKMAN, Y. \& KORKUT, F. (1993). Umut ölçeği üzerine bir çalışma. Hacettepe Üniversitesi Eğitim Fakültesi Dergisi, 9, 193-202.

ALARCON, G. M., BOWLING, N. A. \& KHAZON, S. (2013). Great expectations: A meta-analytic examination of optimism and hope. Personality and Individual Differences, 54(7), 821-827.doi:10.1016/j.paid.2012.12.004

ATAK, H. (2011). Yetişkinliğe geçiş yıllarında sigara içme davranışının psikososyal belirleyicileri ve sigara içmenin yaşam doyumu ve öznel iyi oluşla ilişkisi. Klinik Psikiyatri, 14, 29-43.

AYDIN, G. \& TEZER, E. (1991). İyimserlik, sağlık sorunları ve akademik başarı ilişkisi. Psikoloji Dergisi, 7, 26, 2-9.

BARNUM, D. D., SNYDER, C. R., RAPOFF, M. A., MANI, M. M. \& THOMPSON, R. (1998). Hope and social support in psychological adjustment of children who have survived burn injuries and their matched controls. Children's Health Care, 27(1), 15-30. doi:10.1207/s15326888chc2701_2

BAUMEISTER, R. F. (1991). Meanings of Life. NY: The Guildford Press.

BEN-ZUR, H. (2003). Happy adolescents: The link between subjective well-being, 
Pınar Dursun, “Üniversite Öğrencilerinde Öznel İyi Oluş: Yaşamda Anlam, İyimserlik ve Umudun Rolü”, İstanbul Gelişim Üniversitesi Sosyal Bilimler Dergisi, 8 (2), Ekim 2021, ss. 387-404.

internal resources, and parental factors. Journal of Youth and Adolescence, 32(2), 67-79. doi:10.1023/A:1021864432505

BENTLER, P. M. (2004). EQS Structural Equations Program Manual. Encino, CA: Multivariate Software, Inc.

BRYNE, B. M. (2001). Structural Equation Modeling with AMOS: Basic concepts, applications, and programming. Mahwah, N.J.: Lawrence Erlbaum Associates.

BUSSERI, M. A., CHOMA, B. L. \& SADAVA, S. W. (2009). "As good as it gets" or "the best is yet to come"? How optimists and pessimists view their past, present, and anticipated future life satisfaction. Personality and Individual Differences, 47, 352-356. doi:10.1016/j.paid.2009.04.002

CARVER, C. S., SCHEIER, M. F. \& SEGERSTROM, S. C. (2010). Optimism. Clinical Psychology Review, 30, 879-889.doi:10.1016/j.cpr.2010.01.006

CHANG, E. C. (1998). Hope, problem-solving ability, and coping in a college student population: Some implications for theory and practice. Journal of Clinical Psychology, 54(7), 953-962.doi:10.1002/(SICI)1097-4679(199811)54:7<953::AIDJCLP9>3.0.CO;2-F

CHANG, E. C. \& BANKS, K. H. (2007). The color and texture of hope: Some preliminary findings and implications for hope theory and counseling among diverse racial/ethnic groups. Cultural Diversity and Ethnic Minority Psychology, 13(2), 94103.doi:10.1037/1099-9809.13.2.94

COHEN, J. (1992). A power primer. Psychological Bulletin, 11(2), 155-159. doi:10.1037/0033-2909.112.1.155.

CURRY, L. A., SNYDER, C. R., COOK, D. L., RUBY, B. C. \& REHM, M. (1997). Role of hope in academic and sport achievement. Journal of Personality and Social Psychology, 73(6), 1257-1267. doi:10.1037/0022-3514.73.6.1257

ÇAĞ, P. \& YILDIRIM, İ. (2018). Evlilik doyumunda öznel iyi olma: Yaşam doyumu ve iyimserliğin rolü. Turkish Studies, 13(4), 203-224. doi:10.7827/TurkishStudies.12849

ÇANKAYA, Z. C. \& MEYDAN, B. (2018). Ergenlik döneminde mutluluk ve umut. Electronic Journal of Social Sciences, 17(65), 207-222.

doi:10.17755/esosder.316977

DAUKANTAITE, D. \& ZUKAUSKIENE, R. (2012). Optimism and subjective well being: Affectivity plays a secondary role in the relationship between optimism and global life satisfaction in the middle-aged women. Longitudinal and cross-cultural findings. Journal of Happiness Studies, 13, 1-16. doi:10.1007/s10902-010-9246-2

DECI, E. L. \& RYAN, R. M. (2008). Hedonia, eudaimonia, and well-being: An introduction. Journal of Happiness Studies, 9(1), 1-11. doi:10.1007/s10902-006-9018-1

DENIZ, M. E., ARSLAN, C., ÖZYEŞILL, Z. \& İZMİRLİ, M. (2012). Öz-anlayış, yaşam doyumu, negatif ve pozitif duygu: Türk ve diğer ülke üniversite öğrencileri arasında bir karşılaștırma. Mehmet Akif Ersoy Üniversitesi Ĕ̆itim Fakültesi Dergisi, 12(23), 428-446.

DERINN, S. \& BİLGE, F. (2016). Ergenlerde internet bağımlılığı ve öznel iyi oluş düzeyi. Türk Psikolojik Danışma ve Rehberlik Dergisi, 6(46), 35-51.

DIENER, E. (1984). Subjective well-being. Psychological Bulletin, 95(3), 542-575.

DIENER, E. (2000). Subjective well-being. American Psychologist, 55(1), 34-43. doi:10.1037/0003-066X.55.1.34

DIENER, E., EMMONS, R. A., LARSEN, R. J. \& GRIFFIN, S. (1985). The satisfaction with life scale. Journal of Personality Assessment, 49 (1), 71-75. doi:10.1207/s15327752jpa4901_13

DIENER, E., OISHI, S. \& LUCAS, R. E. (2003). Personality, culture, and subjective well-being: Emotional and cognitive evaluations of life. Annual Review of Psychology, 54, 403-425. doi:10.1146/annurev.psych.54.101601.145056 
DIENER, E. \& RYAN, K. (2009). Subjective well-being: A general overview. South African Journal of Psychology, 39(4), 391-406. doi:10.1177/008124630903900402

DOĞAN, T. (2012). Beş faktör kişilik özellikleri ve öznel iyi oluş. Doğuş Üniversitesi Dergisi, 14(1), 56-64.

DOĞAN, T. \& ERYILMAZ, A. (2013). Benlik saygısı ve öznel iyi oluş arasındaki ilişkilerin incelenmesi. Pamukkale Üniversitesi Eğitim Fakültesi Dergisi, 33(33), 107-117. doi:10.9779/PUJE434

DOGRA, A.K., BASU, S. \& DAS, S. (2011). Impact of meaning in life and reasons for living to hope and suicidal ideation: A study among college students. SIS Journal of Projective Psychology and Mental Health, 18, 89-102.

DURAN, N. O. \& TAN, Şeref, (2013). Minnettarlık ve yaşam amaçları yazma çalışmalarının öznel iyi oluşa etkisi. Türk Psikolojik Danışma ve Rehberlik Dergisi, 4(40), 154-166.

DURSUN, P. (2012). The role of meaning in life, optimism, hope, coping styles in subjective well-being. (Yayınlanmamış Doktora Tezi). Sosyal Bilimler Ensitüsü, Ortadoğu Teknik Üniversitesi, Ankara.

DURSUN, P. \& ALYAĞUT, P. (2020). Meaning in/of Life: Discovery, Invention or Both?. Kıbrıs Türk Psikiyatri ve Psikoloji Dergisi, 2(3), 180-186.

doi:10.35365/ctjpp.20.02.25

DURSUN, P., STEGER, M.F., BENTELE, C.\& SCHULENBERG, S.E. (2016) Meaning

and posttraumatic growth among survivors of the September 2013 Colorado floods. Journal of Clinical Psychology, 72(12), 1247-1263. doi:10.1002/jclp.22344

ERYILMAZ, A. (2011). Ergen öznel iyi oluşu ile olumlu gelecek beklentisi arasındaki ilișkinin incelenmesi. Düşünen Adam Psikiyatri ve Nörolojik Bilimler Dergisi, 24, 209-215. doi:10.5350/DAJPN2011240306

ERYILMAZ, A. \& ERCAN, L. (2016). Öznel iyi oluşun cinsiyet, yaş grupları ve kişilik özellikleri açısından incelenmesi. Türk Psikolojik Danışma ve Rehberlik Dergisi, 4(36), 139-151.

ERYILMAZ, A. \& ATAK, Hasan (2014). Ergen öznel iyi oluşunun, öz saygı ve iyimserlik eğilimi ile ilişkisinin incelenmesi. Elektronik Sosyal Bilimler Dergisi, 10(37), 170-181.

ERYILMAZ, A. \& ÖĞÜLMÜŞ, S. (2010). Ergenlikte öznel iyi oluş ve beş faktörlü kişilik modeli. Ahi Evran Üniversitesi Eğitim Fakültesi Dergisi, 11(3), 189-203.

FORGEARD, M. J. C. \& SELIGMAN, M. E. P. (2012). Seeing the glass half full: A review of the causes and consequences of optimism. Pratiques Psychologiques, 18(2), 107-120.doi:10.1016/j.prps.2012.02.002.

FRANKL, V. E. (1959/1985). Man's search for meaning. (Rev.ed). Oxford, England: Washington Square Press.

FINCAN, M. C. (2019). Ergenlerde algılanan ebeveyn affediciliği ile umut ve iyimserlik arasındaki iliş̧inin incelenmesi (Yayınmamış Yüksek Lisans Tezi). Sosyal Bilimler Enstitüsü, Hasan Kalyoncu Üniversitesi, Gaziantep.

GALLAGHER, M. W. \& LOPEZ, S. J. (2009). Positive expectancies and mental health: Identifying the unique contributions of hope and optimism. Journal of Positive Psychology, 4(6), 548-556. doi:10.1080/17439760903157166

GENÇÖZ, T. (2000). Pozitif ve negatif duygu ölçegi: Geçerlik ve güvenirlik çalışması. Türk Psikoloji Dergisi, 15(46), 19-26.

GREEN, L. S., OADES, L. G. \& GRANT, A. M. (2006). Cognitive-behavioral, solution-focused life coaching: Enhancing goal striving, well-being, and hope. The Journal of Positive Psychology, 1(3), 142-149. doi:10.1080/17439760600619849.

HERERO, V. G. \& EXTREMERA, N. (2010). Daily life activities as mediators of the relationship between personality variables and subjective well-being among older 
adults. Personality and Individual Differences, 49(2), 124-129.

doi:10.1016/j.paid.2010.03.019.

HO, M. Y., CHEUNG, F. M. \& CHEUNG, S. F. (2010). The role of meaning in life and optimism in promoting well-being. Personality and Individual Differences, 48(5), 658663. doi:10.1016/j.paid.2010.01.008.

HO, S., RAJANDRAM, R. K., CHAN, N., SAMMAN, N., MCGRATH, C. \& ZWAHLEN, R. A. (2011). The roles of hope and optimism on posttraumatic growth in oral cavity cancer patients. Oral Oncology, 47(2), 121-124. doi:10.1016/j.oraloncology.2010.11.015.

HU, L. \& BENTLER, P. M. (1999). Cutoff criteria for fit indexes in covariance structure analysis: Conventional criteria versus new alternatives. Structural Equation Modeling, 6, 1-55.

IRVING, L. M., SNYDER, C. R., CHEAVENS, J., GRAVEL, L., HANKE, J., HILBERG, P. \& NELSON, N. (2004). The relationships between hope and outcomes at the pretreatment, beginning, and later phases of psychotherapy. Journal of Psychotherapy

Integration, 14(4), 419-443. doi:10.1037/1053-0479.14.4.419

IRVING, L. M., SNYDER, C. R. \& CROWSON, Jr. J. J. (1998). Hope and coping with cancer by college women. Journal of Personality, 66(2), 195-214. doi:10.1111/14676494.00009

İŞGÖR, İ. Y. (2017). Merhametin Öznel İyi Oluş Üzerindeki Yordayıcı Etkisinin İncelenmesi. Gaziantep Üniversitesi Sosyal Bilimler Dergisi, 16, 425-436. doi: $10.21547 /$ jss.290441.

JU, H., SHIN, J. W., KIM, C. W., HYUN, M. H. \& PARK, J. W. (2013). Mediational effect of meaning in life on the relationship between optimism and well-being in community elderly. Archives of Gerontology and Geriatrics, 56(2), 309-313. doi:10.1016/j.archger.2012.08.008.

KANKOTAN, Z. Z. (2008). The role of attachment dimensions, relationship status, and gender in the components of subjective well-being. (Yayınlanmamış Doktora Tezi). Sosyal Bilimler Enstitüsü, Orta Doğu Teknik Üniversitesi, Ankara.

KASHDAN, T.B. \& STEGER, M.F. (2007). Curiosity and pathways to well-being and meaning in life: Traits, states, and everyday behaviors. Motivation and Emotion, 31, 159173. doi: 10.1007/s11031-007-9068-7.

KATO, T. \& SNYDER, C. R. (2005). The relationship between hope and subjective well-being: Reliability and validity of the dispositional hope scale, Japanese version. Japanese Journal of Psychology, 76(3), 227-234. doi:10.4992/jjpsy.76.227.

KÖKER, S. (1991). Normal ve sorunlu ergenlerin yaşam doyumu düzeyinin karşıllaştırılması. (Yayımlanmamış yüksek lisans tezi). Ankara Üniversitesi, Sosyal Bilimler Enstitüsü, Ankara

KULU, A. U. (2019). Ortaokul öğrencilerinde umut, iyimserlik ve Allah tasavvuru iliş̧kisi. (Yayınlanmamış yüksek lisans tezi). Sosyal Bilimler Enstitüsü, Marmara Üniversitesi, İstanbul.

KÜMBÜL GÜLER, B. \& EMEÇ, H. (2006). Yaşam memnuniyeti ve akademik başarıda iyimserlik etkisi. Dokuz Eylül Üniversitesi İktisadi ve İdari Bilimler Fakültesi Dergisi, 21(2), 129-149.

LUCAS, R. E., DIENER, E. \& SUH, E. (1996). Discriminant validity of well-being measures. Journal of Personality and Social Psychology, 71(3), 616-628. doi:10.1037/0022-3514.71.3.616.

MARTELA, F. \& STEGER, M.F. (2016). The three meanings of meaning in life: Distinguishing coherence, purpose, and significance. The Journal of Positive Psychology, 11(5), 531-545. doi:10.1080/17439760.2015.1137623.

MACCALLUM, R. C., ROZNOWSKI, M. \& NECOWITZ, L. B. (1992). Model modifications in covariance structure analysis: The problem of capitalization on 
chance. Psychological Bulletin, 111(3), 490-504. doi:10.1037/0033-2909.111.3.490

MERCAN, O. (2019). Ergenlerde karar verme stillerinin öznel iyi oluş ve umut ile ilişskisi. (Yayımlanmamış yüksek lisans tezi). Sosyal Bilimler Enstitüsü, Ankara Üniversitesi, Ankara.

MYERS, D. G. \& DIENER, E. (1995). Who is happy?. Psychological Science, 6(1), 10-19.

ÖZTÜRK, A. (2013). Uludağ üniversitesi eğitim fakültesi öğrencilerinin öznel iyi oluş düzeyleri ile tinsellik, iyimserlik, kaygı ve olumsuz duygu düzeyleri arasındaki ilişki, (Yayımlanmamış yüksek lisans tezi). Sosyal Bilimler Enstitüsü, Uludağ Üniversitesi, Bursa.

PARK, C. L. (2010). Making sense of the meaning literature: an integrative review of meaning making and its effects on adjustment to stressful life events. Psychological Bulletin, 136(2), 257. doi:10.1037/a0018301.

PARK, C. L. \& FOLKMAN, S. (1997). Stability and change in psychosocial resources during caregiving and bereavement in partners of men with AIDS. Journal of Personality, 65, 421-447. doi:10.1111/j.1467-6494.1997.tb00960.x.

PARK, N., PARK, M. \& PETERSON, C. (2010). When is the search for meaning related to life satisfaction. Applied psychology: Health and Well-being, 2(1), 1-13. doi: 10.1111/j.1758-0854.2009.01024.x.

RESNICK, S.G., FONTANA, A., LEHMAN, A.F. \& ROSENHECK, R.A., (2005). An empirical conceptualization of the recovery orientation. Schizophrenia Research, 75, 119-128. doi:10.1016/j.schres.2004.05.009.

REKER, G. T. (2005). Meaning in life of young, middle-aged, and older adults: Factorial validity, age, and gender invariance of the Personal Meaning Index (PMI). Personality and Individual Differences, 38(1), 7185.doi:10.1016/j.paid.2004.03.010.

RYAN, R. M. \& DECI, E. L. (2000). Self-determination theory and the facilitation of intrinsic motivation, social development, and well-being. American Psychologist, 55(1), 68-78. doi:10.1037/0003-066X.55.1.68.

RYFF, C. D. (1989). Happiness is everything, or is it? Explorations on the meaning of psychological well-being. Journal of Personality and Social Psychology, 57(6), 10691081. doi:10.1037/0022-3514.57.6.1069

SAĞKAL, A. S. \& TÜRNÜKLÜ, A. (2017). Barıș eğitimi programının lise öğrencilerinin öznel iyi oluş ve umut düzeyleri üzerindeki etkileri. Türk Psikolojik Danışma ve Rehberlik Dergisi, 7(47), 69-85.

SATAN, A. A. (2014). Dini inanç ve bilişsel esneklik düzeylerinin öznel iyi oluş düzeyine olan etkisi. 21. Yüzyılda Eğitim ve Toplum, 3(7), 56-74.

SCHEIER, M. F. \& CARVER, C.S. (1985). Optimism, coping and health: Assessment and implications of generalized outcome expectancies. Health Psychology, 4(3), 219-247. doi:10.1037/0278-6133.4.3.219

SCHERMELLEH-ENGEL, K., MOOSBRUGGER, H. \& MÜLLER, H. (2003). Evaluating the fit of structural equation models: tests of significance and descriptive goodness-of-fit measures. Methods of Psychological Research Online, 8, 23-74.

SCHULENBERG, S. E., STRACK, K. M. \& BUCHANAN, E. M. (2011). The meaning in life questionnaire: Psychometric properties with individuals with serious mental illness in an inpatient setting. Journal of Clinical Psychology, 67, 1210-1219. doi:10.1002/jclp.20841.

SCHUMAKER, R. E. \& LOMAX, R. G. (1996). A Beginner's guide to structural modeling. Lawrence Erlbaum Associates, Mahwah, NJ.

SEGERSTROM, S. C. (2007). Optimism and resources: Effects on each other and on health over 10 years. Journal of Research in Personality, 41(4), 772-786. 
Pınar Dursun, “Üniversite Öğrencilerinde Öznel İyi Oluş: Yaşamda Anlam, İyimserlik ve Umudun Rolü”, İstanbul Gelişim Üniversitesi Sosyal Bilimler Dergisi, 8 (2), Ekim 2021, ss. 387-404.

doi:10.1016/j.jrp.2006.09.004.

SHOREY, H. S., LITTLE, T. D., SNYDER, C. R., KLUCK, B. \& ROBITSCHEK, C. (2007). Hope and personal growth initiative: A comparison of positive, future-oriented constructs. Personality and Individual Differences, 43, 1917-1926. doi:10.1016/j.paid.2007.06.011.

SNYDER, C.R. (2002). Hope theory: Rainbows in the mind. Psychological Inquiry: An International Journal for the Advancement of Psychological Theory, 13(4), 249-275. doi:10.1207/S15327965PLI1304_01.

SNYDER, C.R., FELDMAN, D. B., TAYLOR, J., SCHROEDER, L. L. \& ADAMS, V. H. (2000). The roles of hopeful thinking in preventing problems and enhancing strengths. Applied and Preventive Psychology, 9, 249-270. doi:10.1016/S0962-1849(00)80003-7.

SNYDER, C.R., HARRIS, C., ANDERSON, J. R., HOLLERAN, S. A., IRVING, L., SIGMON, S.T. et al. (1991). The will and the ways: development and validation of an individualdifferences measure of hope. Journal of Personality and Social Psychology, 60, 570-585. doi:10.1037/0022-3514.60.4.570.

SNYDER, C. R., RAND, K. L., KING, E. A., FELDMAN, D. B. \& WOODWARD, J.T. (2002). "False" hope. Journal of Clinical Psychology, 58(9), 1003-1022. doi: 10.1002/jclp.10096

SOLBERG NES, L. \& SEGERSTROM, S. C. (2006). Dispositional optimism and coping: A meta-analytic review. Personality and Social Psychology Review, 10(3), 235-251. doi:10.1207/s15327957pspr1003_3.

STEGER, M. F. (2012). Making meaning in life. Psychological Inquiry, 23(4), 381385. doi:10.1080/1047840X.2012.720832.

STEGER, M.F. \& FRAZIER, P. (2005). Meaning in life: one link in the chain from religiousness to well-being. Journal of Counseling Psychology, 52(4), 574-582. doi:10.1037/0022-0167.52.4.574.

STEGER, M.F., FRAZIER, P., OISHI, S. \& KALER, M. (2006). The meaning in life questionnaire: Assessing the presence of and search for meaning in life. Journal of Counseling Psychology, 53(1), 80-93. doi:10.1037/0022-0167.53.1.80

STEGER, M.F. \& KASHDAN, T.B. (2007). Stability and specificity of meaning in life and life satisfaction over one year. Journal of Happiness Studies, 8, 161-179. doi:10.1007/s10902-006-9011-8.

STEGER, M. F., OISHI, S. \& KASHDAN, T. B. (2009). Meaning in life across the lifespan: Levels and correlates of meaning in life from emerging adulthood to older adulthood. The Journal of Positive Psychology, 4(1), 43-52.

doi:10.1080/17439760802303127.

STEGER, M. F., OWENS, G.P. \& PARK, C.L. (2015). Violations of war: Testing the meaning-making model among Vietnam veterans. Journal of Clinical Psychology, 71(1), 105-116. doi:10.1002/jclp.22121.

SÜMER, N. (2000). Yapısal eşitlik modelleri: Temel kavramlar ve örnek uygulamalar. Türk Psikoloji Yazıları, 3(6), 49-74.

ŞIMSSEK, Ö. F. (2005). Paths from fear of death to subjective well-being: A study of structural equation modeling based on the terror management theory perspective. (Yayınlanmamış Doktora Tezi), Sosyal Bilimler Enstitüsü, Ortadoğu Teknik Üniversitesi, Ankara.

ŞIMSSEK, Ö. F. (2007). Yapısal eşitlik modellemesine giriş: Temel ilkeler ve LISREL uygulamaları. Ankara: Ekinoks Yayınevi.

TAGAY, Ö. \& BALTACI, H. Ş. (2017). Ergenlerde öznel iyi oluş ve zaman tutumu: Benlik saygısı ve iyimserliğin aracı rolü. Pamukkale Üniversitesi Eğitim Fakültesi Dergisi, 41(41), 131-144. 
TARHAN, S. \& BACANLI, H. (2015). Sürekli Umut Ölçeği'nin Türkçe'ye uyarlanması: Geçerlik ve güvenirlik çalışması. The Journal of Happiness \& WellBeing, 3(1), 1-14.

TÜRKMEN, M. (2012). Öznel iyi oluşun yapısı ve anababa tutumları, özsaygı ve sosyal destekle ilișkisi: Bir model sınaması. Ușak Üniversitesi Sosyal Bilimler Dergisi, 5(1), 41-73.

UTSEY, S. O., HOOK, J. N., FISCHER, N. \& BELVET, B. (2008). Cultural orientation, ego resilience, and optimism as predictors of subjective well-being in African Americans. The Journal of Positive Psychology, 3(3), 202-210. doi:10.1080/17439760801999610

WATSON, D., CLARK, L. A. \& TELLEGEN, A. (1988). Development and validation of brief measures of positive and negative affect: The PANAS scale. Journal of Personality and Social Psychology, 54, 1063-1070. doi: 10.1037/0022-3514.54.6.1063.

WERNER, S. (2012). Subjective well-being, hope, and needs of individuals with Serious mental illness. Psychiatry Research, 196(2), 214-219.

doi:10.1016/j.psychres.2011.10.012.

WONG, S. S. \& LIM, T. (2009). Hope versus optimism in Singaporean adolescents: Contributions to depression and life satisfaction. Personality and Individual Differences, 46, 648-652. doi:10.1016/j.paid.2009.01.009.

WORTMANN, J. H. \& PARK, C. L. (2009). Religion/spirituality and change in meaning after bereavement: Qualitative evidence for the meaning making model. Journal of Loss and Trauma, 14(1), 17-34.doi:10.1080/15325020802173876.

YALÇIN, İ. (2015). İyi oluş ve sosyal destek arasındaki ilişkiler: Türkiye'de yapılmış çalışmaların meta analizi. Türk Psikiyatri Dergisi, 26(1), 21-32. doi:10.5080/u7769.

YALÇIN, İ. (2011) Social support and optimism as predictors of life satisfaction of college students. International Journal for the Advancement of Counselling, 33, 79-87. doi:10.1007/s10447-011-9113-9.

YILMAZ, E. \& ALTINOK, V. (2009). Okul yöneticilerinin yalnızlık ve yaşam doyu düzeylerinin incelenmesi. Kuram ve Uygulamada Ĕ̆itim Yönetimi, 15(59), 451-469.

YURCU, G., KOCAKULA, Ö. (2015). Konaklama işletmelerinde çalışan yalnızlığının öznel iyi oluş üzerine etkisi. Adnan Menderes Üniversitesi Sosyal Bilimler Enstitüsü Dergisi, 2(1), 30-41.

\section{Summary}

Subjective Well-Being (SWB), which is usually used interchangeably with happiness is composed of two primary components: cognitive component which refers to a general life satisfaction; and emotional component, concerning the presence of positive affect and absence of negative affect. A meaningful life is considered as an inevitable component of a happy life. The meaning process has two distinct dimensions: Search for Meaning and Presence of Meaning. The other important strength of a person is hopefulness which is occasionally used as interchangeably with optimism, even though many studies revealed that they are related but different constructs. Similar to hope, one of the important strengths of a person is his ability to think optimistically about future. The purpose of this study is to explore the relationships among meaning in life (presence and search), optimism, hope, and life satisfaction and positive affect components of subjective well-being as well as to test the predictive contributions of all these variables on subjective well-being or happiness within the framework of a model.

Survey data was collected from 1160 volunteered students from different faculties and grades of Afyon Kocatepe University. Statistical analyses were carried out with a sample 
of 984 (582 female and 402 male) students with the mean age of $21.26(S D=1.69)$. The study was conducted with ethical permission from Afyon Kocatepe University and Middle East Technical University. Meaning in Life Questionnaire, Life Orientation Test, The Hope Scale, Positive and Negative Affect Schedule and Satisfaction with Life Scale were administered to the participants of the study.

Pearson correlation coefficient analysis revealed that positive emotion was positively correlated with optimism $(r=.26, p<.01)$, hope $(r=.53, p<.01)$ and presence of meaning ( $r=.23, p<.01$ ) unlike search for meaning, that had no significant relationship. Negative emotion was found to be negatively associated with presence of meaning $(r=-.19$, $p<.01)$, optimism $(r=-.38, p<.01)$ and hope scores $(r=-.27, p<.01)$, and positively correlated with search for meaning $(r=.17, p<.01)$. Similarly, life satisfaction was positively associated with presence of meaning ( $r=.35, p<.01)$, optimism $(r=.41, p<.01)$, and hope $(r=.37, p$ $<.01)$. As expected, satisfaction with life scores were negatively related to search for meaning $(r=-.21, p<.01)$.

In order to find out unique contributions and associations of these variables on happiness scores, structural equation modeling (SEM) through EQS program was conducted with two steps. In the first step, we performed measurement model due to find the relationship with latent variables (meaning in life and subjective well-being) and their indicators (two subscales of meaning in life and two scales of subjective well-being). In the second step, the structural model was run to examine the associations among latent variables (hope, optimism, meaning in life and happiness). In the third stage, the subscales of meaning in life taken as a latent variable, hope, optimism and positive emotion and negative emotion and life satisfaction variables taken as indicators of the structural model was tested. However, this model in the last step failed to fit the data properly. As modification index (Lagrange Multiplier Test) suggestion, a covariation error was added between the subscales of meaning in life. As a result of this modification, model provided a good fit to the data. This model explained 65\% of the total variance. As shown in Figure 1, presence of meaning $(\beta=.35, p<.05)$, hope $(\beta=.24, p<.05)$, optimism $(\beta=.65, p<.05)$ and search for meaning $(\beta=-.12, p<.05)$ had a direct and significant path to happiness.

This study suggested that the construct of happiness (latency variable) can be appropriately represented by three components (indicators) based on the measurement models. As a result of SEM, it was seen that all variables significantly predicted subjective well-being or happiness. More specifically, optimistic and hopeful individuals who have meaning in their lives exhibit higher levels of happiness, whereas individuals who search for meaning in their lives have lower levels of happiness. Interestingly, hope did not emerge as powerful predictor as optimism. This study revealed that the perception of happiness which is characterized by positive emotion, negative emotion and life satisfaction, were associated with presence of meaning in life, being optimistic and hopeful. Among them, optimism was found to be the most powerful predictor in determining happiness. 